\title{
Direction of Action in Translating the Yari-Morai Expression
}

\author{
Reny Wiyatasari* \\ Japanese Language and Culture Study Program, Faculty of Humanities, Diponegoro University, Jl \\ Prof Soedarto (Diponegoro University), Semarang, Central Java, Indonesia.
}

\begin{abstract}
This research is descriptive qualitative research using case study on Japan's manga translation by Japanese Student in Diponegoro University. The study aims to determine how students' understanding of the concept of shiten with the results of student translations of the expression of yari-morai. The subject of research are Japanese students at Diponegoro University whom already joining the translation class. The data sources of this study are Japanese manga documents and their translations, and questionnaires that contain the results of translation of yari-morai sentences. Data collection method used in this study was structured interviews through questionnaires. Based on the results of the questionnaire, it is known that several students have sufficiently understood the direction of action which contains the activities of giving and taking on $\sim$ teyaru and $\sim$ teageru expressions, but not on $\sim$ tekureru and -temorau expressions, and general students' understanding of the direction of action in the yari-morai expression does not match their ability to translate this expression.
\end{abstract}

\section{Introduction}

Translation is commonly understood as trasforming a text written in one language into an equivalent text in a different language (Hasegawa, 2012). Therefore, when someone is involved in the field of translation, in addition to knowledge of the culture of source language and target language, he needs to equip himself with good language skills as an important factor in the accuracy of the translation. One example of the difficulties faced by a translator is due to differences in language systems, such as differences in structure, meaning, and socio-culture between Source language and target language. Therefore, mastery of Source language and Target language or linguistic competencies, such as morphological, lexical, and grammatical systems are requirements that must be fulfilled by a translator.

A translator also plays a vital role in determining the meaning of sentences. The meaning of the sentence specified by the translator will give the reader an idea of interpreting a translation. In contrast to oral communication, in written language, confirmation of the contents of a message cannot always be done directly by the recipient of the message to the sender of the message. This is one of the difficulties in translating

\footnotetext{
${ }^{*}$ Corresponding author : reny.wiyatasari@gmail.com
} 
written language. This paper tries to analyze the translation of speech containing the verb yari-morai which acts as a supplementary verb (hojodoushi) and is used to express the activities/actions of giving and receiving services that contain the meaning of goodness, profit, gratitude, etc. Therefore, in the give-receive activity, a direction is drawn from whom to whom an action (which implies goodness, profit, gratitude) is carried out. Unlike the Japanese language, the Indonesian language itself is not clearly drawn the direction of action and to whom an action is done. The difference between the concepts of 'giving' and 'receiving' in Japanese and Indonesian is one of the difficulties when translating speech that contains this yari-morai expression. Therefore, in this article, the writer is interested in raising the issue of the direction of action of activities or actions in translating speech that contains the yari-morai expressions to find out whether the respondent's understanding. As source of the data, this article uses manga or Japanese comic and supported by a list of questions that support analysis to answer the problem formulation.

Theories that the writer uses as a reference or basis, including the following. The theory about shiten or point of view put forward by Iori et al. (2001) and Kuno (1996:129) which basically states that expressions with the verb give-and-take always describe events from the perspective of the speaker. In sentences using kureru auxiliary verb, the subject is definitely not a speaker.

Kuno (1996) states that the kureru auxiliary verb is only used in the case that the speaker's perspective is directed towards the non-subject (pasientif) rather than the subject (actor). Conversely, for yaru (ageru) auxiliary verb is used in terms of the perspective of the speaker more directed to the subject (actor) rather than non-subject (pasientif). Kuno's statement in the context of the speaker stands as a party that is not directly involved in actions involving meaningful yari-morai activities

\section{Method}

In this study, a questionnaire method was used involving respondents, namely 20 Japanese Faculty of Humanities students who had passed in the translation course. Meanwhile, secondary data was obtained through relevant literature reference studies to support the accuracy of primary data. Data were analyzed using descriptive methods and the theories of Iori et al. (2001) and Kuno (1996). Regarding the problem formulation, a column in the questionnaire is requested that asks students to translate and a choice column about the direction of movement from whom to/for whom. Examples are as follows:

Based on the direction of the speaker's perspective, the direction of speech acts:

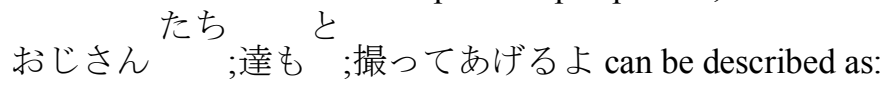

\begin{tabular}{|l|l|l|l}
\hline a. $\mathrm{A} \longrightarrow \mathrm{B}$ & b. $\mathrm{A} \longrightarrow \mathrm{C}$ & c. $\mathrm{A} \longrightarrow \mathrm{BC}$ & d. $\mathrm{BC} \longrightarrow \mathrm{A}$
\end{tabular}

From the results of both, then analyzed to find out whether the ability of students in answering the direction of action based on the concept of shiten (point of view) in accordance with their ability to translate speech containing yari-morai which is measured by using the level of accuracy and acceptance based on Nababan et al.' (2012) theory. 


\section{Results and Discussion}

The point of view or shiten becomes the reference from the position where we see an object or target. In Japanese, the viewpoint is expressed from the speaker, and this can be seen from the forms $\sim$ temorau and $\sim$ tekureru, In temoraubun (sentences with the auxiliary verb morau), the speaker is placed as subject. Meanwhile, in tekureru, the direction of action is always towards the speaker without placing the speaker as the subject (Kuno, 1996; Iori 2001). The following is a description of the students' understanding of the direction of the action that contains the activities of giving and taking based on the concept of shiten in the translation of the phrase yari-morai along with the results of the translation.

\subsection{The Direction of Action in Translating the rteageru and $\sim$ teyaru expressions}

From the analysis of data based on the incoming questionnaire, it is known that the ability of students to answer questions about the direction of the actions or activities depicted in the speech is sufficient in accordance with their ability to translate speech that contains the expressions $\sim$ teageru and teyaru. The following is the speech data of $\sim$ teageru and reyaru:

Data 1.

おじさん達も撮ってあげるよ

Ojisantachimo totteageruyo

'I photographed Uncles too'.

Data 2.

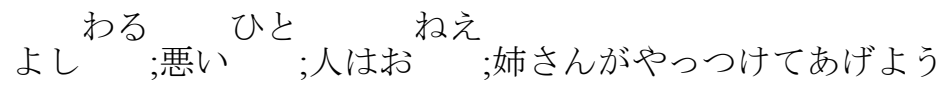

Yoshiwaruihitowa oneesanga yattsuketeageyoo

'He is a bad guy, leave him to me'

Data 3.

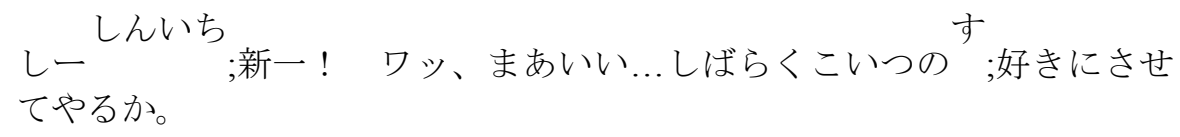

Shi..Shinichi..!Waa, maa ii...shibaraku koitsunosukini saseteyaru

'Shi..Shinichi! Huft.. Let it be .. Just follow first what he wants.

Data 4.

だいじょうぶだ。よつばが教えてやる。

Daijoobuda. Yotsuba ga oshieteyarui.

'Take it easy. Yotsuba will teach'.

Based on the questions in the questionnaire about the perspective of the verb -teageru in data 1 , it is known that $100 \%$ of students answered the questions correctly. In data 1 , the direction of movement which involves the give-receive activity is from me (the speaker) to the uncles (interlocutors). These results are directly proportional to the results of the translation because almost students have translated correctly and in terms of quality 
including accurate and acceptable translations. Whereas in data 2, it is known that only $30 \%$ of students answered the questions correctly the direction of the movement involving the give-receive activity, namely Brother (speaker) to B (interlocutor/sister). In general, students respond from speakers to $\mathrm{O} 3$ (bad guy). However, this result is inversely proportional to the results of the translation because about $90 \%$ of students have translated it quite well, although in terms of quality there are still translations that are less accurate and less acceptable. For example: Yes, Brother will defeat the bad guy. Furthermore, data 3 found that $70 \%$ of students answered the questions correctly. In this data 3, based on the point of view, the direction is from A (speaker) and B (interlocutor) to O3 (Shinichi). This result is directly proportional to the translation produced, because $80 \%$ of students have translated it quite well, although in terms of quality there are results that are less accurate and less acceptable. For example: Shi... Shinichi! Oh well... Do we let him do the thing he likes? In data 4, it is known that $100 \%$ of respondents answered the direction of the action was from Yotsuba (speaker) to $\mathrm{O} 2$ (interlocutor), but only $50 \%$ of students were able to translate quite well.

Example: It's OK. Yotsuba will teach.

\subsection{The Direction of Action in Translating the temorau expression}

From the analysis of data obtained, it is known that the ability of students to answer questions about the direction of the action or activity illustrated in the speech is not in accordance with their ability to translate speech that contains expressions $\sim$ temorau. The following explanation

\section{Data 1 .}

テレビ 持って行ってもらうの

Terebi motteittemorauno

'Should we ask the one who helps bring the television?'

In data 1 , the direction of movement which involves the give-receive based on the speaker's point of view is from $\mathrm{O} 3$ to $\mathrm{B}$ (speaker) and A (interlocutor of B). From the questions in the questionnaire above, it is known that $50 \%$ of students answered the questions correctly. While the results of the translation show that $70 \%$ of students translate correctly.

\subsection{The Direction of Action in Translating the rekureru expression}

From the analysis of data obtained, it is known that most students still make mistakes in answering questions about the direction of the action or activity depicted in the speech and this correlates with their ability to translate speech that contains the $\sim$ tekureru expression. Following is the speech data of $\sim$ teageru and $\sim$ teyaru:

Data 1.

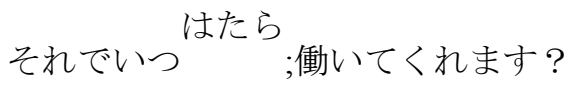

Sorede itsuhataraitekuremasu?

Then, when can you start working? 
Data 2.

あれだけいれば、話を聞いてくれる死霊がいるかも!

Aredakeireba, hanashio kiitekureru shiryooga irukamo

'If there is that much, maybe there is a Soul who wants to listen to my story!'

Based on the questions in the questionnaire, it is known that only $40 \%$ of students answer questions correctly about the direction of the give-receive. From the point of view, the direction is from B (interlocutor) to A (speaker). Likewise from the translation results, it is known that only $50 \%$ percent of students are able to translate quite well, and in terms of quality, there are still inaccurate translations, one of which is the example: When did you work for me?

Meanwhile, in data 2 it is known that only $30 \%$ of students answered questions correctly about the direction of the give-receive movement based on the point of view, from shiryoo (spirit) to A (speaker). This correlates with the translation results because only $20 \%$ of students can translate correctly.

\section{Conclusion}

Based on the results of the questionnaire, it is known that most students have sufficiently understood the direction of the action which contains the give-and-take activity based on the concept of shiten on the expression of $\sim$ teyaru and teageru, and this is in accordance with the ability of students to translate these expressions. On the contrary, students' understanding of the direction of action on the expression of $\sim$ tekureru and temorau is still not good, and this is not in accordance with the ability of students to translate these two expressions, because most students are able to translate it quite well. Thus, students' general understanding of the direction of action in the yari-morai expression is not in accordance with their ability to translate these expressions. 


\section{References}

1. Hasegawa, Yoko. The Routledge Course In Japanese Translation. Routledege. London and New York (2012)

2. Iori, Isao et al.Nihon-go Bunpou Handobukku. Toukyou :

Suriiee Nettowaku (2000)

3. ---------. Nihongo Bunpou Handobukku. Toukyou (2001)

4. Koizumi, Tamotsu. Gengo Nyuumon. Tokyo: Taishukan Shoten (1993)

5. Kuno, Susumu. Danwa no Bunpou. Toukyou. Taishuukan Shoten (1996)

6. Mahsun. Metode Penelitian Bahasa. Jakarta: PT Raja GrafindoPersada (2005)

7. Matsura, Kenji. Kamus Bahasa Jepang-Indone sia. Kyoto: Kyoto Sangyo University Press (1994)

8. Nababan, M, dkk, (2012) Pengembangan Model penilaian Kualitas Terjemahan. Kajian Linguistik dan Sastra, 24 (1), hlm 35-57.

9. Nababan, Rudolf. Teori Menerjemah Bahasa Inggris. Yogyakarta: Pustaka Pelajar (1999)

10. Nide, E dan Taber, C. 1982. The Theory And Practice Of Translation. Leiden: E.J. Brill (1982)

11. Sagawa et al. Nihongo Bunkei Jiten. Tokyo: Kuroshio (1998)

12. Gosho, Aoyama. Meitantei Konan. Vol.1-6.. Shogakukan: Japan. (1994)

13. Toka, Adachi. Noragami Vol. 1. Shounen Magazine: Japan. (2013)

14. Azuma, Kiyohiko.Yotsubato.Vol 1. Kadokawa: Japan (2003) 